\title{
6,6'-Dihydroxythiobinupharidine (DTBN) Purified from Nuphar lutea Leaves Is an Inhibitor of Protein Kinase C Catalytic Activity
}

\author{
Kamran Waidha ${ }^{1,+}+\mathbb{D}$, Nikhil Ponnoor Anto ${ }^{2,+} \mathbb{D}$, Divya Ram Jayaram ${ }^{2,+}{ }^{\mathbb{D}}$, Avi Golan-Goldhirsh ${ }^{3, *}$, \\ Saravanakumar Rajendran $4, *$ (D), Etta Livneh ${ }^{2, *, \ddagger}$ and Jacob Gopas $2,5, *, \ddagger$ (D)
}

1 Defence Institute of High Altitude Research (DIHAR), Defence Research and Development Organisation (DRDO) Leh, Ladakh UT-194101, India; kamranwaidha1@gmail.com

2 The Shraga Segal Department of Microbiology, Immunology and Genetics Faculty of Health Sciences, Ben-Gurion University of the Negev, Beer Sheva 8400501, Israel; antop@post.bgu.ac.il (N.P.A.); jayaram@post.bgu.ac.il (D.R.J.)

3 The Jacob Blaustein Institutes for Desert Research (BIDR), Sede Boqer Campus, French Associates Institute for Agriculture and Biotechnology of Drylands, Ben-Gurion University of the Negev, Beer Sheva 8499000, Israel

4 Chemistry Division, Vellore Institute of Technology Chennai Campus, School of Advanced Sciences, Chennai 600127, India

5 Department of Oncology, Soroka University Medical Center, Beer Sheva 8400501, Israel

* Correspondence: avigolan@bgu.ac.il (A.G.-G.); sar.org@gmail.com (S.R.); etta@bgu.ac.il (E.L.); jacob@bgu.ac.il (J.G.)

check for updates

Citation: Waidha, K.; Anto, N.P.; Jayaram, D.R.; Golan-Goldhirsh, A.; Rajendran, S.; Livneh, E.; Gopas, J. 6,6'-Dihydroxythiobinupharidine (DTBN) Purified from Nuphar lutea Leaves Is an Inhibitor of Protein Kinase C Catalytic Activity. Molecules 2021, 26, 2785. https://doi.org/ $10.3390 /$ molecules 26092785

Academic Editor: Micholas Dean Smith

Received: 15 April 2021

Accepted: 5 May 2021

Published: 8 May 2021

Publisher's Note: MDPI stays neutral with regard to jurisdictional claims in published maps and institutional affiliations.

Copyright: (c) 2021 by the authors. Licensee MDPI, Basel, Switzerland. This article is an open access article distributed under the terms and conditions of the Creative Commons Attribution (CC BY) license (https:// creativecommons.org/licenses/by/ $4.0 /)$. $+\quad$ These authors contributed equally to this work.

$\ddagger$ These authors contributed equally to this work.

Abstract: Water lily (Nuphar) bioactive extracts have been widely used in traditional medicine owing to their multiple applications against human ailments. Phyto-active Nuphar extracts and their purified and synthetic derivatives have attracted the attention of ethnobotanists and biochemists. Here, we report that 6,6'-dihydroxythiobinupharidine (DTBN), purified from extracts of Nuphar lutea (L.) Sm. leaves, is an effective inhibitor of the kinase activity of members of the protein kinase C (PKC) family using in vitro and in silico approaches. We demonstrate that members of the conventional subfamily of PKCs, PKC $\alpha$ and PKC $\gamma$, were more sensitive to DTBN inhibition as compared to novel or atypical PKCs. Molecular docking analysis demonstrated the interaction of DTBN, with the kinase domain of PKCs depicting the best affinity towards conventional PKCs, in accordance with our in vitro kinase activity data. The current study reveals novel targets for DTBN activity, functioning as an inhibitor for PKCs kinase activity. Thus, this and other data indicate that DTBN modulates key cellular signal transduction pathways relevant to disease biology, including cancer.

Keywords: protein kinase C (PKC); Nuphar lutea; 6,6'-dihydroxythiobinupharidine (DTBN); kinase inhibitor; Ramachandran plot; homology docking modeling

\section{Introduction}

Natural products of Nuphar lutea (L.) Sm. (Nymphaeaceae) have been widely used for treating inflammatory conditions in ethnic medicine [1,2]. A systematic review of early studies revealed that the full therapeutic potential of Nuphar products is still largely unexplored by modern research [3]. Nevertheless, recent reports from various laboratories, including ours, on the medicinal properties of semi-purified Nuphar extracts (NUP) have indicated potential applications. We have previously published that a semi-purified leaf extract from yellow water lily, Nuphar lutea (L.) Sm. (NUP), is enriched in sesquiterpene thioalkaloids, such as nupharidine and bi-nupharidine isomers [4]. A variety of therapeutic applications have been described: anti-inflammatory [2], antibacterial [5,6], antiviral [1], against pathogenic fungi [7], against leishmania, and trypanosome parasites, [8-10], and against cancer. We previously examined the effect of NUP extracts in 
B16 melanoma, experimental murine lung metastasis model, and in a variety of cell lines, demonstrating its ability to affect ERK and NF-KB pathways. We showed that combined NUP and cisplatin treatment was synergistic and reduced the lung metastatic load. In addition, NUP treatment inhibited TNF $\alpha$-induced I $\kappa \mathrm{B} \alpha$ degradation and NF- $\kappa \mathrm{B}$ nuclear translocation. We also observed that NUP induced ERK activation. Furthermore, ERK inhibition prevented NF- $\mathrm{KB}$ inactivation by NUP $[5,11,12]$. We have recently published that $6,6^{\prime}$-dihydroxythiobinupharidine (DTBN), purified from NUP, very efficiently and covalently inhibited human type II topoisomerase [13]. Lastly, we recently published that the purified molecule primes neutrophils against bacteria present in gum inflammation, enhances phagocytosis, ROS production, and NET formation [14]. We hypothesize that the mechanism of action of nupharidines goes via the electrophilic thiaspirane warhead of nupharidine(s), which targets a nucleophilic cysteine at the active site of cysteine proteases, and potentially other enzymes. This mechanism may explain the pleiotropic effect of this family of compounds [15]. Being pleiotropic and not limited to a single molecular target may be advantageous.

The protein kinase C (PKC) family comprised a group of serine/threonine kinases which transduce a multitude of signals that control diverse cellular processes, such as proliferation, migration, invasion, differentiation, apoptosis, transcription, and translation [16,17]. Aberrant PKC activity or localization has been linked to numerous diseases, including cancer [18], pain [19], and neurodegenerative diseases [20]. PKC comprises nine genes that share a similar architecture, with an N-terminal regulatory moiety and a C-terminal kinase domain [21,22]. PKC members are classified into three major structurally and functionally distinct subfamilies, including conventional or classical PKC (cPKCs: $\alpha, \beta$, and $\gamma$ ), novel PKC (nPKCs: $\delta, \varepsilon, \eta, \theta$ ), and atypical PKC (aPKCs: $\iota / \lambda$ and $\zeta$ ) isoforms [21-23].

Numerous observations from basic studies and clinical trials have implicated PKC in the pathophysiology of diverse types of diseases, including cancer $[24,25]$. PKCs are involved in different signaling pathways, including ERK and NF-kB, suggesting that PKCs could be a target for NUP activity [26].

Our results show that DTBN inhibits PKC isoforms, preferentially conventional PKCs. In silico molecular docking analysis of DTNB to these enzymes confirmed our results, and provides a structural basis for the interaction of DTNB with PKCs.

\section{Results}

\subsection{Protein Kinase $C$ (PKC) Inhibition Assay}

To test the effect of DTBN on the activity of PKC isoforms, in vitro kinase assays were performed in a dose-response experiment, and results are presented in Figure 1. At these concentrations, the kinase activities of PKCs were inhibited by DTBN in a dose-dependent manner, having the most profound effect on conventional PKC $\alpha$ and PKC $\gamma$ as compared to other PKCs tested (Figure 1 and Table 1). To calculate the median inhibitory concentration $\left(\mathrm{IC}_{50}\right)$, the relative amounts of $\mathrm{p}^{32}-\mathrm{MBP} / \mathrm{MBP}$ were plotted at several DTBN concentrations: $\mathrm{IC}_{50}=0.174 \mu \mathrm{M}(\mathrm{PKC} \alpha), 0.168 \mu \mathrm{M}(\mathrm{PKC} \gamma), 14.23 \mu \mathrm{M}(\mathrm{PKC} \varepsilon), 18.6 \mu \mathrm{M}$ (PKC $\left.\zeta\right)$, and $>19 \mu \mathrm{M}$ $(\mathrm{PKC} \eta$ and $\mathrm{PKC} \delta$ ). Immunoblotting was performed with antibodies against HA-tagged different PKCs and against Myelin Basic Protein (MBP) as a loading control.

Table 1. Inhibition of PKC isoforms by DTBN.

\begin{tabular}{ccc}
\hline PKC Isoforms & IC $_{\mathbf{5 0}}$ Values $(\mu \mathrm{g} / \mathbf{m L})$ & IC $_{\mathbf{5 0}}$ Values $(\boldsymbol{\mu M})$ \\
\hline PKC $\alpha$ & 0.092 & 0.174 \\
PKC $\gamma$ & 0.089 & 0.168 \\
PKC $\varepsilon$ & 7.5 & 14.23 \\
PKC & $>10$ & $>19$ \\
PKC $\zeta$ & 9.8 & 18.6 \\
PKC $\delta$ & $>10$ & $>19$ \\
\hline
\end{tabular}




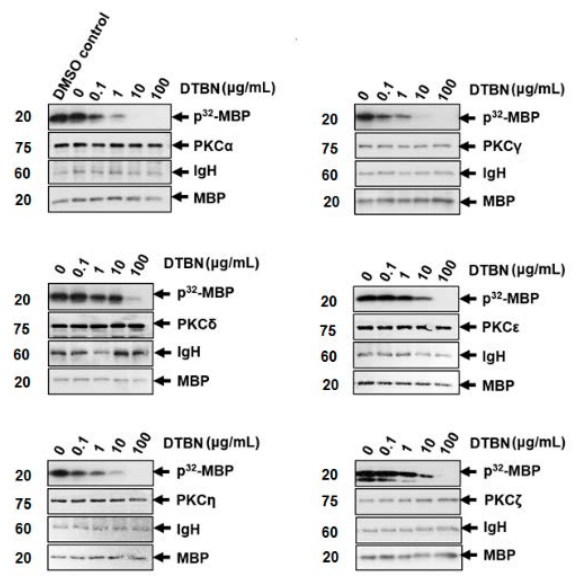

(a)

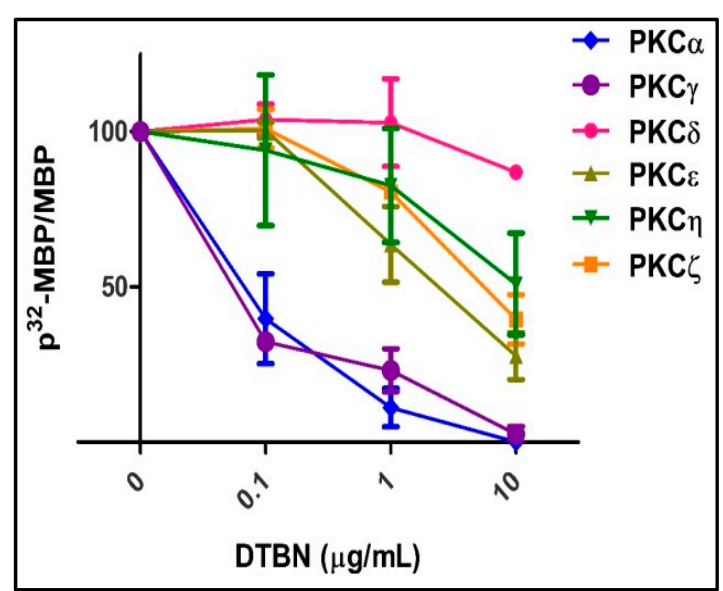

(b)

Figure 1. DTBN downregulates PKC catalytic activity in a concentration-dependent manner. In vitro kinase assays of indicated PKC isoforms were performed, as described in Materials and Methods, utilizing MBP as a substrate. Before the initiation of the assay, DTBN was added to the samples at several concentrations. Following the termination of the assay, sample proteins were then resolved by SDS-PAGE and developed by autoradiography (a). $\mathrm{p}^{32}$-MBP and MBP protein band signals were quantified using Image Lab software, and the relative amounts of $\mathrm{p}^{32}-\mathrm{MBP} / \mathrm{MBP}$ were presented in a line graph (b). Immunoblotting against HA and MBP to detect overexpressed PKC expression, and MBP, respectively, monitor equal loading of samples. Data are representative of two independent experiments. Molecular weight markers (in kDa) are indicated on the left, and arrows mark the positions of the indicated protein bands. IgH, Ig heavy chain.

\subsection{Molecular Docking of DTBN to PKC Isoforms}

Using molecular docking of DTBN to individual PKCs, we demonstrate binding of DTBN to the ATP binding pocket of PKCs, with PKC $\alpha$ exhibiting the deepest insertion into the ATP binding pocket, followed by PKC $\gamma$. Post mm-GBSA refinement binding energy (Table 2) strongly correlated with the in vitro results. DTBN has the highest binding energy to conventional PKCs ( $\alpha$ and $\gamma$ ) and lowest to PKC $\delta$ and $\zeta$. The difference in binding energy may be due to the interaction of DTBN with amino acid residues at the active site and the extent to which the DTBN fits into the ATP binding pocket of PKC isoforms.

Table 2. Results of molecular docking.

\begin{tabular}{|c|c|c|c|}
\hline PKC Isoforms & $\begin{array}{c}\Delta G \text { Bind } \\
\text { * } \\
(\mathrm{Kcal} / \mathrm{mol}) \text { of DTBN }\end{array}$ & Control Molecule & $\begin{array}{l}\Delta \mathrm{G} \mathrm{Bind} * \\
(\mathrm{Kcal} / \mathrm{mol})\end{array}$ \\
\hline $\mathrm{PKC} \alpha$ & -40.83 & NVP-AEB071 & -71.92 \\
\hline PKC $\gamma$ & -30.74 & GO6983 & -57.18 \\
\hline $\mathrm{PKC} \varepsilon$ & -23.25 & NVP-AEB071 & -44.22 \\
\hline $\mathrm{PKC \eta}$ & -20.73 & 2,6-Naphthyridine & -56.52 \\
\hline $\mathrm{PKC \zeta}$ & -19.61 & - & - \\
\hline PKCठ & -19.0 & NVP-AEB071 & -61.35 \\
\hline
\end{tabular}

* post mm-GBSA refinement.

\section{Discussion}

The inclusion of DTBN inhibited the ability of PKCs to phosphorylate their substrate MBP, myelin basic protein, in a dose-dependent manner (Figure 1). The inhibitory activity of DTBN was most effective against members of the conventional families PKC $\alpha$ and PKC $\gamma$, with PKC $\alpha$ and PKC $\gamma$ almost equally affected by DTBN, especially at a low drug concentration $\left(\mathrm{IC}_{50}=0.174\right.$ and $0.168 \mu \mathrm{M}$, Table 1$)$. The novel $\mathrm{PKC}$ isozyme, $\mathrm{PKC} \varepsilon$, was

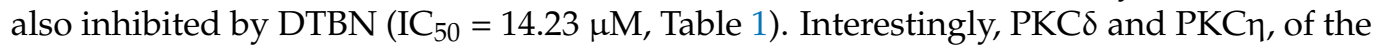
novel subclass, were the least affected upon DTBN inclusion in the kinase assay system $\left(\mathrm{IC}_{50}>19 \mu \mathrm{M}\right.$ each, Table 1). Similar observations were also noted on PKC $\mathrm{P}\left(\mathrm{IC}_{50}=18.6 \mu \mathrm{M}\right.$, Table 1), a member from the atypical PKC family. Taken together, our results demonstrate 
DTBN as an inhibitor of PKC catalytic activity, with conventional PKCs being the most affected, especially PKC $\alpha$ and PKC $\gamma$.

As mentioned in the introduction, we previously reported the anti-inflammatory, anticancer, and antibacterial properties of Nuphar semipurified extracts (NUP) and purified DTBN. Our studies provided evidence for the phytoactive ability of NUP in modulating various cell signaling cascades. For instance, it enhanced ERK activation, which resulted in a decreased activity of TNF $\alpha$-induced NF- $\mathrm{KB}$. DTBN also was shown to covalently inhibit human type II topoisomerase activity, an observation that highlighted the possibility of DTBN behaving as a potent inhibitor of human enzymes by targeting their active sites [13]. Here, we demonstrate that DTBN is a PKC inhibitor. Considering the inhibitory effect of DTBN on NF- $\mathrm{KB}$, we propose that PKCs, and in particular PKC $\alpha$ and PKC $\gamma$, mediate this DTBN effect on NF- $\mathrm{kB}$, and perhaps other signaling cascades in which DTBN was shown to be involved. Indeed, numerous reports linked PKCs to NF- $\kappa B$ signaling in various cancers [27-30]. For example, PKC $\alpha$ was shown to activate NF- $\kappa B$, while PKC $\delta$ downregulated NF- $\mathrm{KB}$ activation [31]. Thus, PKCs could be a target for NUP activity. To understand the varied inhibitory activity of DTBN against PKC isoforms, molecular docking was conducted.

To understand the inhibitory action and molecular interactions of DTBN with PKC isoforms, DTBN was docked to the ATP binding site of PKC isoforms. PKC catalytic domain consists of an amino $\left(-\mathrm{NH}_{2}\right)$ terminal lobe, which is made up of $\beta$-sheets and contains the ATP binding domain, which is rich in glycine and has a consensus sequence of GXGXXG and an invariant lysine. The carboxylic (-COOH) end domain mostly comprises $\alpha$-helical structures and contains an activation loop. Multiple sequence alignment and ATP binding site of all PKC isoforms $(\alpha, \delta, \eta, \varepsilon$ and $\gamma$ ) are highly conserved (GKGSFG), except for PKC $\zeta$ (Figure 2); there is variation in the ATP binding site sequence (GRGSYA: Gly264 into Ala264, Phe263 into Tyr263, and Lys260 into Arg260).
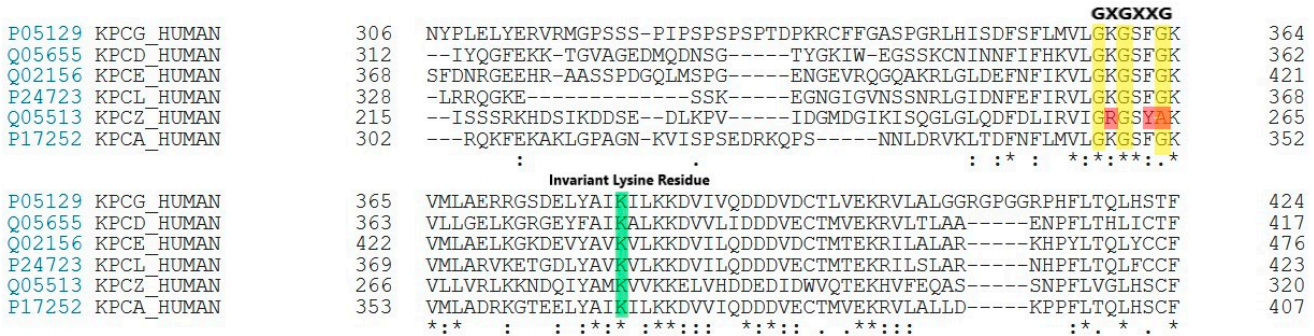

Figure 2. ATP binding kinase domain site alignment and invariant lysine residue of PKC isoforms. Red: Denotes variation in the ATP binding site residue of PKC) (GRGSYA: Gly264 into Ala264, Phe263 into Tyr263, and Lys260 into Arg260). Yellow: Conserved Glycine Rich region of ATP Binding site across PKC isoforms, Green: Invariant Lysine Residue across PKC isoforms which structures the enzyme for phosphoryl-transfer. * Denotes position which has fully conserved amino acid residues across multiple sequences. ":" Denotes conservation between groups of strong similar properties. "." Denotes conservation between groups of weakly similar properties.

DTBN binds deep into the ATP binding cleft of PKC $\alpha$, surrounded by $\beta$-sheets on its sides (Figure 3), with binding score of $-40.83 \mathrm{Kcal} / \mathrm{mol}$ (Table 2). At the active site, DTBN is stabilized by two hydrogen bonds and $\pi \ldots \pi$ interactions (Table 3). On the other hand, co-crystallized inhibitor NVP-AEB071 at the PKC $\alpha$ active site $\left(\mathrm{IC}_{50}: 2.09 \mathrm{nM}\right)$ is stabilized by four hydrogen bond interactions [32]. These strong interactions play a crucial role in the activity, as well as a binding affinity $(-71.92 \mathrm{Kcal} / \mathrm{mol})$. 


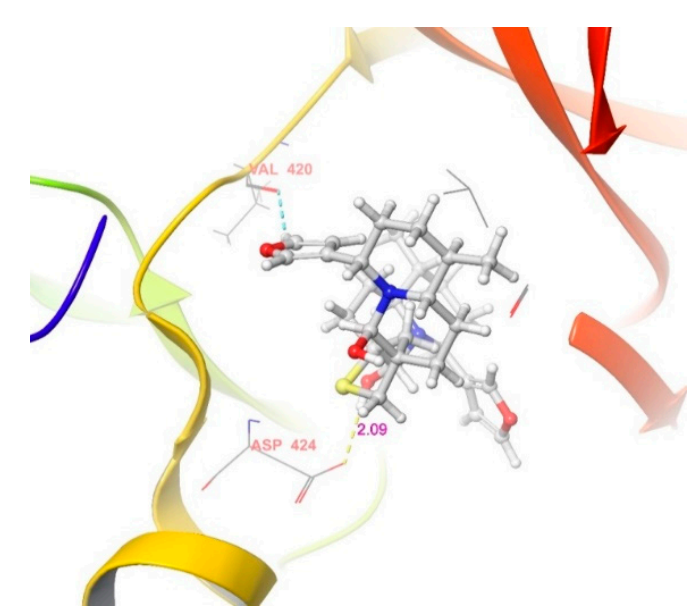

(a)

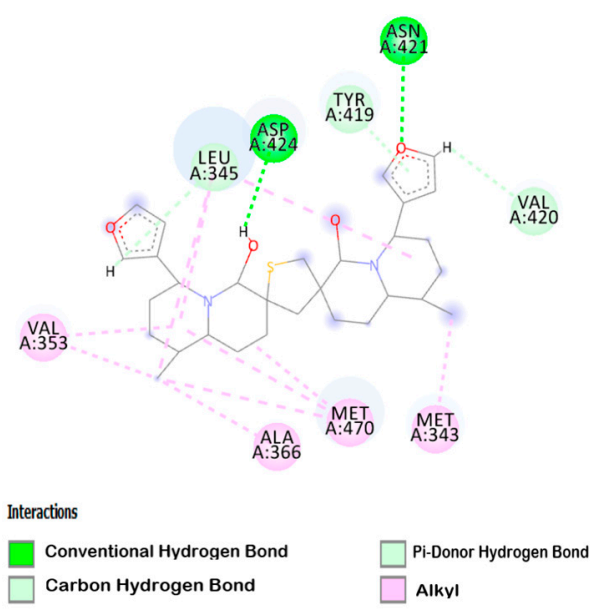

(b)

Figure 3. DTBN at PKC $\alpha$ binding pocket (a) 3D image and (b) 2D image.

Table 3. Interaction of DTBN in binding pocket of different PKC isoforms.

\begin{tabular}{|c|c|c|}
\hline PKC Isoforms & H-Bond Interaction & $\pi \cdots \pi$ and $\pi \cdots S$ Interaction \\
\hline PKC $\alpha$ & $\begin{array}{l}\text { (i) }-\mathrm{NH} \text { hydrogen of Asn } 421 \text { and furan ring }-\mathrm{O} \text { of } \mathrm{DTBN}(\mathrm{N}-\mathrm{H} \cdots \mathrm{O}, 2.91 \AA) \\
\text { (ii) carboxylic oxygen }(-\mathrm{OH}) \text { of } \mathrm{Asp} 424 \text { and hydrogen of }-\mathrm{OH} \text { group proximal to } \\
\text { thiophene sulphur in DTBN }(\mathrm{O}-\mathrm{H} \cdots \mathrm{O}, 2.09 \AA) \\
\text { (iii) }-\mathrm{CH} \text { hydrogen of furan ring in DTBN and carboxylic oxygen }(\mathrm{C}=\mathrm{O}) \text { of Leu } 345 \\
(\mathrm{C}-\mathrm{H} \cdots \mathrm{O}, 2.43 \AA)\end{array}$ & $\begin{array}{l}\pi \cdots \pi \text { interaction between phenyl and } \\
\text { furan ring of Tyr } 419 \text { and DTBN, } \\
\text { respectively }(2.24 \AA)\end{array}$ \\
\hline PKC $\gamma$ & $\begin{array}{l}\text { carboxylic oxygen }(-\mathrm{OH}) \text { of Asp441 and hydrogen of }-\mathrm{OH} \text { proximal to the } \\
\text { thiophene sulfur in } \mathrm{DTBN}(\mathrm{O}-\mathrm{H} \cdots \mathrm{O}, 2.41 \AA)\end{array}$ & $\begin{array}{l}\pi \cdots \pi \text { interaction between phenyl and } \\
\text { furan ring of Phe } 362 \text { and DTBN }(4.80 \AA) \text {. } \\
\pi \cdots S \text { interaction between S and furan } \\
\text { ring of Cys636 and DTBN, respectively } \\
(4.29 \AA) .\end{array}$ \\
\hline $\mathrm{PKC \varepsilon}$ & $\begin{array}{l}\text { (i) side-chain carboxylic oxygen }(\mathrm{C}=\mathrm{O}) \text { of } \mathrm{Asp} 536 \text { and hydrogen of }-\mathrm{OH} \text { group } \\
\text { proximal to thiophene sulphur in DTBN }(\mathrm{O}-\mathrm{H} \cdots \mathrm{O}, 1.91 \AA \text { ) } \\
\text { (ii) } \mathrm{C}-\mathrm{H} \cdots \mathrm{O} \text { aromatic hydrogen bond between }(\mathrm{a}) \text { furan ring hydrogen of DTBN } \\
\text { and side-chain carboxylic oxygen }(\mathrm{C}=\mathrm{O}) \text { of Asp536 }(2.68 \AA) \text { and carboxylic oxygen } \\
\text { (C=O) of Lys416 }(2.79 \AA) \\
\text { (b) furan ring hydrogen of DTBN and side-chain carboxylic oxygen }(\mathrm{C}=\mathrm{O}) \text { of amino } \\
\text { acid residue Asp699 (2.51 } \AA \text { ) }\end{array}$ & $\begin{array}{l}\pi \cdots \pi \text { interaction between phenyl and } \\
\text { furan ring of Phe } 419 \text { and DTBN, } \\
\text { respectively ( } 4.90 \AA \text { ). }\end{array}$ \\
\hline PKC $\eta$ & $\begin{array}{l}\text { carboxylic oxygen }(-\mathrm{OH}) \text { of } \mathrm{Asp} 440 \text { and carboxylic oxygen }(\mathrm{C}=\mathrm{O}) \text { of } \mathrm{Asp} 483 \\
\text { involved in hydrogen bond with }-\mathrm{OH} \text { group proximal to thiophene sulphur in } \\
\text { DTBN (two } \mathrm{O}-\mathrm{H} \cdots \mathrm{H}, 2.31 \text { and } 2.88 \AA \text {, respectively) }\end{array}$ & $\begin{array}{l}\text { (i) } \pi \cdots S \text { interaction between phenyl and } \\
\text { thiophene sulphur of } \\
\text { Phe } 366 \text { and DTBN, respectively }(5.02 \AA) \text {. } \\
\text { (ii) } \pi \cdots \text { S interaction between furan ring } \\
\text { and sulphur of DTBN and Met } 442 \text {, } \\
\text { respectively ( } 4.72 \AA \text { ). }\end{array}$ \\
\hline PKC $\zeta$ & $\begin{array}{l}\text { (i) side-chain hydroxy oxygen of Ser } 262 \text { and carboxylic oxygen }(-\mathrm{OH}) \text { of } A \text { sp } 380 \\
\text { involved in hydrogen bond with }-\mathrm{OH} \text { groups of DTBN (two O-H } \cdots \mathrm{O}, 1.98 \text { and } \\
1.96 \AA \text {, respectively) } \\
\text { (ii) phenyl hydrogen of amino acid residue Phe } 552 \text { and furan oxygen of nupharidine } \\
\text { (aromatic } \mathrm{C}-\mathrm{H} \cdots \mathrm{O}, 3.23 \AA \text { ) }\end{array}$ & 1 \\
\hline PKCठ & - & - \\
\hline
\end{tabular}

Unlike PKC $\alpha$, the binding pocket of PKC $\gamma$ is closed by a random coil and there is a slight shift in the $\beta$-sheets in comparison to $\mathrm{PKC} \alpha$, which resulted in fewer interactions contributing to the decreased binding score $(-30.74 \mathrm{Kcal} / \mathrm{mol}$, Table 2$)$. At the binding site, a steric clash is observed between the furan ring of DTBN and the amino group of Arg634 in the random coil, which, in addition, contributes to the decreased binding score (Figure 4). However, the DTBN is stabilized by $\mathrm{H}$-bond interaction and $\pi$-interactions, such as $\pi \ldots \pi$ and $\pi \ldots$ interactions at the binding site (Table 3 ). 

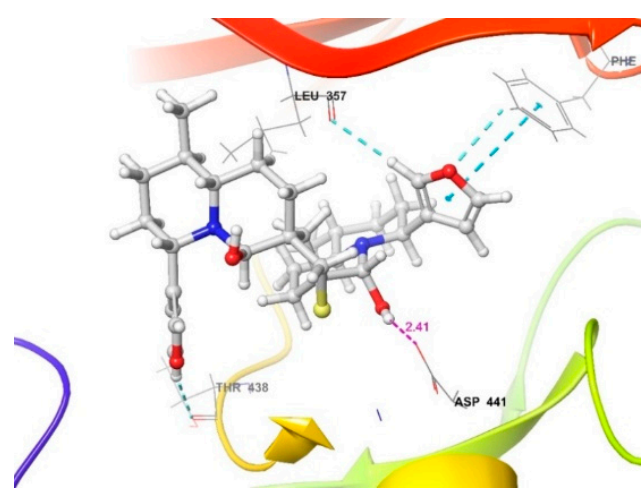

(a)

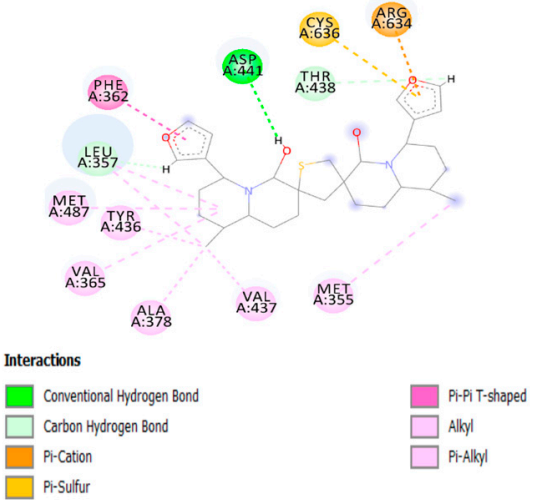

(b)

Figure 4. DTBN at PKC $\gamma$ binding pocket (a) 3D image and (b) 2D image.

In correlation with in vitro results, DTBN showed a weak binding affinity with the novel and atypical PKCs (Table 2). The weak binding score was attributed to a smaller binding pocket and, hence, limited space for access and accommodation of DTBN at the active site of these kinases (Figure 5, Figure 6, Figure 7, Figure 8). Due to the smaller binding pocket, DTBN at PKC $\varepsilon$ experiences two steric clashes-one between the methyl group of DTBN and amino group $(-\mathrm{NH})$ of Asp699 residue, and the other between the methylene $\left(-\mathrm{CH}_{2}\right)$ of octahydro- $1 \mathrm{H}$-quinolizine ring in DTBN and carboxylic -OH of Asp493 residue. This weakens the ligand-enzyme interaction and contributes to a reduced binding score $(-23.25 \mathrm{Kcal} / \mathrm{mol}$, Table 2$)$. Although it is destabilized by steric clash, it is stabilized by $\mathrm{O}-\mathrm{H} \cdots \mathrm{O}$ and $\mathrm{C}-\mathrm{H} \cdots \mathrm{O}$ hydrogen bonds at the active site (Figure 5).

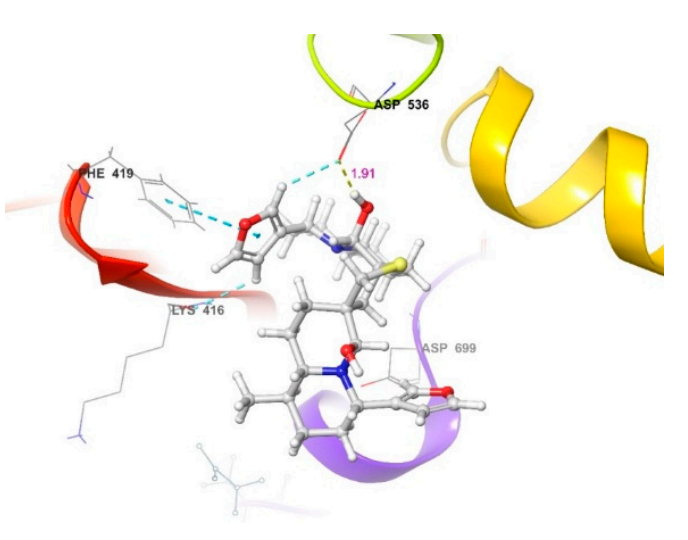

(a)

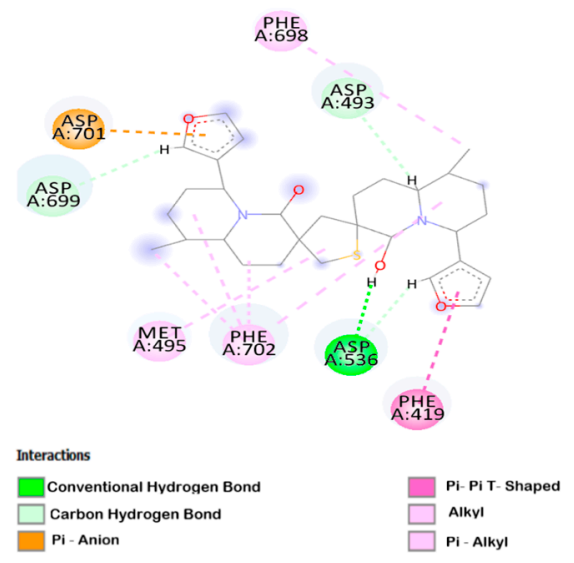

(b)

Figure 5. DTBN at PKC $\varepsilon$ binding pocket (a) $3 \mathrm{D}$ image and (b) $2 \mathrm{D}$ image.

Similarly, a smaller binding pocket of PKC $\eta$ to accommodate DTBN leads to a steric clash between the octahydro- $1 \mathrm{H}$-quinolizine ring methylene $\left(-\mathrm{CH}_{2}\right)$ group of DTBN and the amino group (-NH) of Asp645 present in the loop next to the binding pocket (Figure 6). A smaller binding pocket and steric interaction weakens the ligand-enzyme interaction and contributes to a lower binding score $(-20.73 \mathrm{Kcal} / \mathrm{mol}$, Table 2$)$. At the active site, DTBN is stabilized by hydrogen bond and $\pi \ldots . . S$ interactions (Table 3$)$. In comparison, the co-crystallized inhibitor naphthyridine at $\mathrm{PKC} \eta\left(\mathrm{IC}_{50}: 9 \mathrm{nM}\right)$ is stabilized by three hydrogen bonds [33], whereas DTBN is stabilized by only one hydrogen bond. This accounts for the low binding score of DTBN.

The low binding score of $\mathrm{PKC} \eta$ in comparison to $\mathrm{PKC} \varepsilon$ is attributed to the presence of a single-turn $\alpha$-helix near the PKC $\varepsilon$ binding pocket, which results in several weak interactions

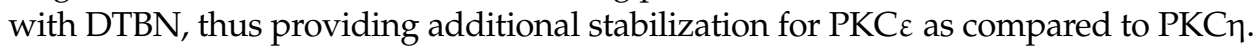




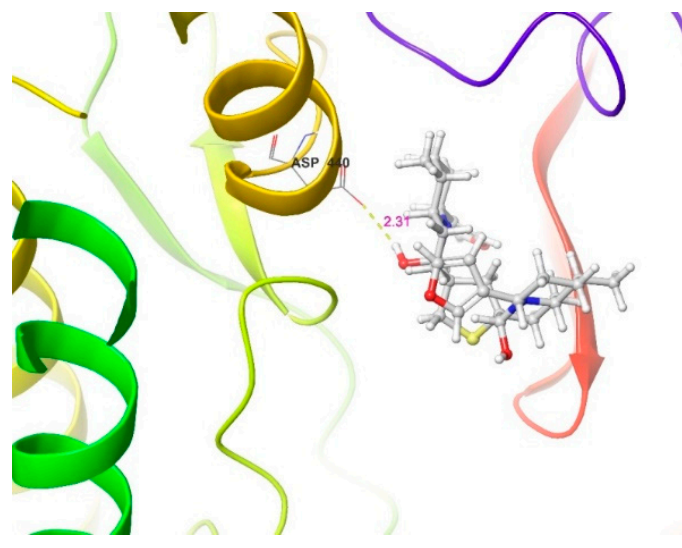

(a)

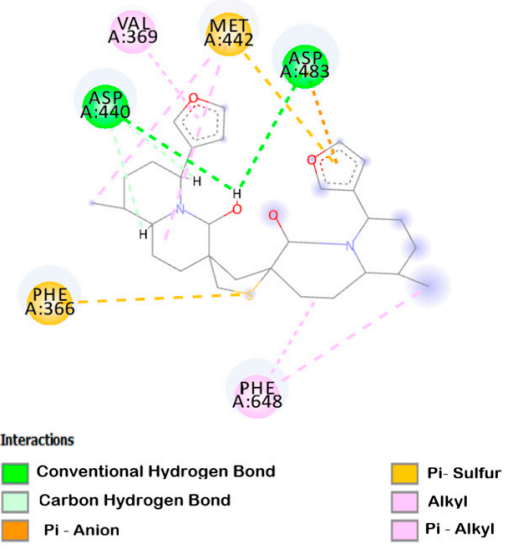

(b)

Figure 6. DTBN at PKC $\eta$ binding pocket (a) 3D image and (b) 2D image.

Alike $\mathrm{PKC} \varepsilon$ and $\mathrm{PKC} \eta$ the binding pocket of $\mathrm{PKC} \delta$ and $\mathrm{PKC} \zeta$ are also smaller to accommodate DTBN in the ATP binding pocket without steric clash (Figure 7), leading to fewer stabilizing interactions at the active site $(-19.0$ and $-19.61 \mathrm{Kcal} / \mathrm{mol}$ respectively, Table 2). At the PKC $\zeta$ active site, a steric clash is observed between thiophene sulfur of DTBN and the protonated guanidine amino group (-NH) of Lys378 (Figure 7 (bottom)). This contributes to its lowest binding score. However, DTBN is stabilized by two $\mathrm{O}-\mathrm{H} \cdots \mathrm{O}$ and a $\mathrm{C}-\mathrm{H} \cdots \mathrm{O}$ hydrogen bonds (Table 3 ).

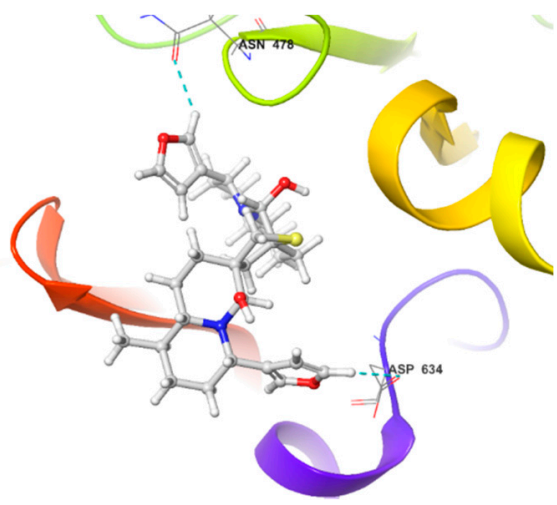

(a)

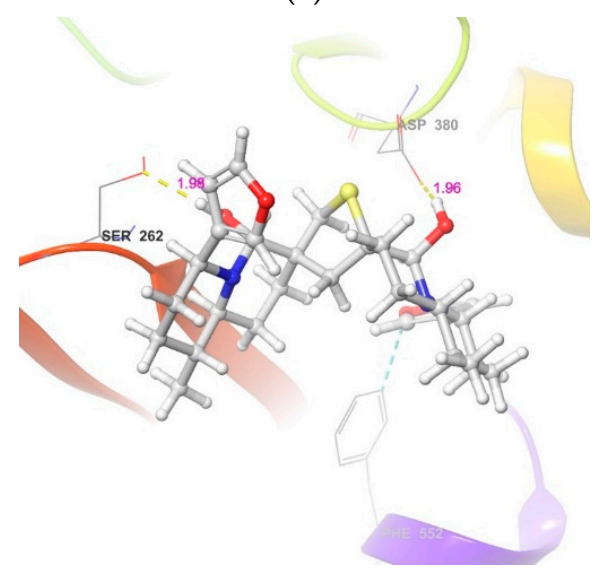

(c)

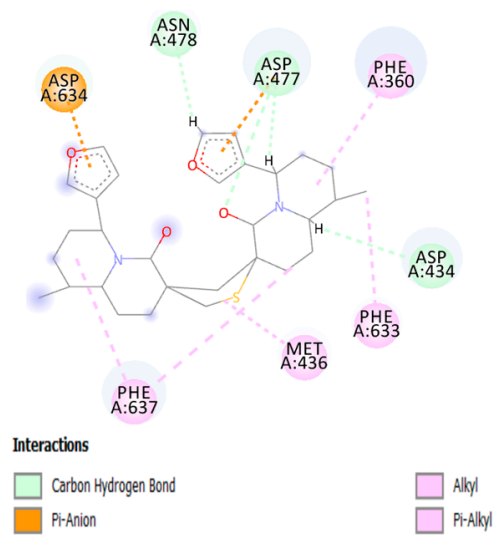

(b)

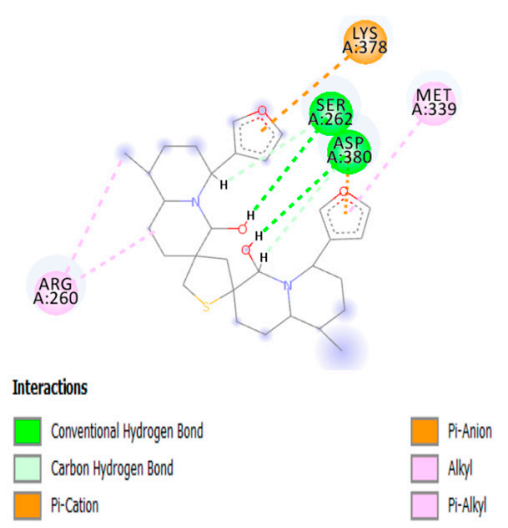

(d)

Figure 7. DTBN at PKC $\delta$ (top) and PKC $\zeta$ (bottom) binding pockets (a) and (c) 3D images, and (b,d) 2D images. 
In Figure 8, a comparison of DTBN at the ATP binding pocket of PKC $\alpha$ and PKC $\delta$ is shown. It is apparent that DTBN binds deep into the ATP binding pocket of PKC $\alpha$, whereas the accommodation of DTBN at the ATP bind site of PKC $\delta$ is restricted due to a smaller binding pocket.

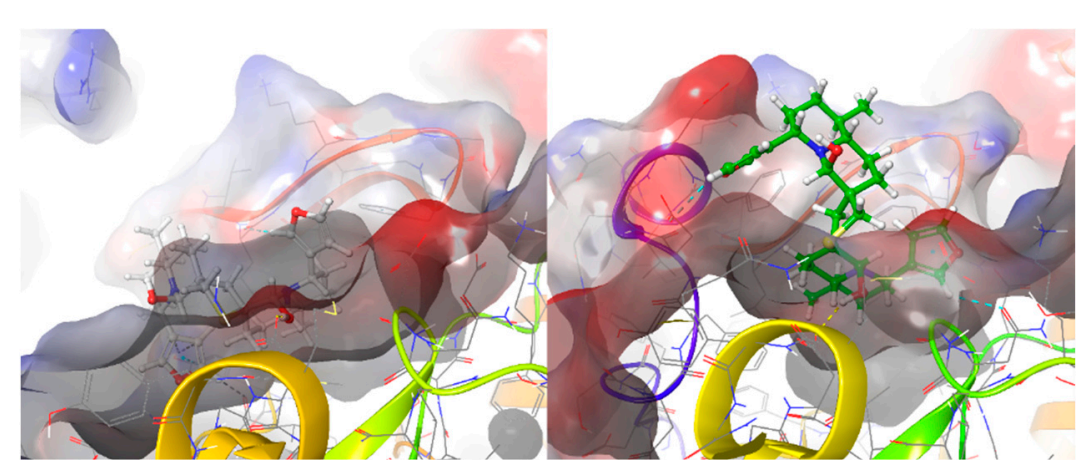

Figure 8. Comparison of DTBN in the binding pocket of PKC $\alpha$ (left) and PKC $\delta$ (right).

\section{Materials and Methods}

\subsection{Materials}

6,6'-dihydroxythiobinupharidine (DTBN) was purified from Nuphar lutea extracts and purchased from Sigma (St. Louis, MO, USA)/Merck (Darmstadt, Germany), cat. SMB00609. DTBN was dissolved in DMSO.

\subsection{Methodology}

\subsubsection{In Vitro Kinase Assay}

PKC kinase assays were performed, as described [34], using myelin-basic protein $(5 \mu \mathrm{g} / 100 \mu \mathrm{L})(\mathrm{MBP}$, \#M1891, Sigma-Aldrich, St. Louis, MO, USA) as a substrate. Wholecell lysates (75 $\mu$ g per sample) of HEK-293T cells, each overexpressing different HA-tagged PKCs, were subjected to immunoprecipitation using protein A/G-agarose bead-immobilized anti-HA mAbs (\#MMS-101R, BioLegend, San Diego, CA, USA). The immunoprecipitates were washed four times with Triton X-100-containing lysis buffer, and lastly with PKC kinase assay buffer (20 mM HEPES, pH 7.5, $10 \mathrm{mM} \mathrm{MgCl}_{2}$, and $0.1 \mathrm{mM}$ EGTA). The immunoprecipitates were then equally divided to Eppendorf safe-lock tubes, followed by the addition of indicated concentrations of DTBN $(\mu \mathrm{g} / \mathrm{mL})$ and subsequent incubation in a kinase reaction mixture (10 $\mathrm{mM} \mathrm{MgCl}_{2}, 20 \mathrm{mM}$ HEPES, $0.1 \mathrm{mM}$ EGTA, $50 \mu \mathrm{g} / \mathrm{mL}$ phosphatidylserine, and $5 \mu \mathrm{Ci} \gamma$-32P-ATP (PerkinElmer, Waltham, MA, USA), also including $100 \mu \mathrm{M}$ cold ATP and $1.5 \mathrm{mM} \mathrm{CaCl}_{2}$ (for conventional PKCs), and incubated for $30 \mathrm{~min}$ at $32{ }^{\circ} \mathrm{C}$ with gentle shaking. Reactions were terminated by the addition of $5 \times$ sample buffer and boiling for $5 \mathrm{~min}$, followed by SDS-PAGE ( $10 \%$ acrylamide gels) under reducing conditions. Samples were then transferred to nitrocellulose membranes (Sigma-Aldrich) that were developed by immunoblotting and autoradiography. After the detection of the phosphorylated substrate ( $\left.{ }^{32} \mathrm{P}-\mathrm{MBP}\right)$ by autoradiography, the membranes were probed with anti-HA and anti-MBP mAbs (\#SMI-99P, BioLegend, San Diego, CA, USA), (loading controls). ${ }^{32} \mathrm{P}-\mathrm{MBP}$ and MBP protein bands were quantified using Image Lab software (5.2.1).

\subsubsection{Molecular Docking and MM-GBSA Refinement}

Molecular docking studies were performed using Schrödinger Maestro Suite 2020-3 (Schrödinger, LLC, New York, NY, USA). DTBN was docked to the ATP binding site of PKC isoforms. X-ray crystallographic structures of PKC $\alpha$ (PDB ID: 3IW4) and PKC $\eta$ (PDB ID: 3TXO) are available in RCSB PDB. The structures of other PKC isoforms, $\delta, \gamma, \varepsilon$, and $\zeta$ were generated using a homology modelling approach using a Swiss model online server (https:/ / swissmodel.expasy.org/) (accessed on 20 December 2020) [35]. The homologybased models were further validated using the Swiss model inbuilt structure assessment, ERRAT, and ProSA [36,37]. 


\subsubsection{Homology Modelling and Structural Validation}

Since the crystal structures of PKC isoform $\delta, \gamma, \varepsilon$, and $\zeta$ were not reported earlier, the homology modelling approach was adopted to develop their structures. The templates chosen for model generation are given in Table 4. The $Q_{\text {mean }}$ scores of the generated models were above -2.0. $Q_{\text {mean }}$ score provides the "degree of nativeness" of the model [38]. A $\mathrm{Q}_{\text {mean }}$ score near ' 0 ' represents a good agreement between the predicted model structure and experimental structures of similar size. It also helps in the estimation of the quality of the generated models. Structure assessment details are given in Table 5. Further, an assessment of the Ramachandran plot (Figures 9 and 10) of all the generated structures shows greater than $93 \%$ of core residues were in the favoured region; thus, suggesting generated models of PKC-isoforms were of good quality and reliable.

Table 4. Homology models properties.

\begin{tabular}{llllllll}
\hline $\begin{array}{l}\text { Protein } \\
\text { Model }\end{array}$ & Template & $\begin{array}{l}\text { Seq. } \\
\text { Identity }\end{array}$ & $\begin{array}{l}\text { Seq. } \\
\text { Similarity }\end{array}$ & Coverage & GQME & Q $_{\text {mean }}$ & Range \\
\hline PKC $\boldsymbol{\gamma}$ & 3IW4.1.A & $76.99 \%$ & 0.55 & 0.49 & 0.35 & -1.78 & $345-686$ \\
PKC $\delta$ & 5f9e.1.A & $72.99 \%$ & 0.53 & 0.49 & 0.32 & -0.41 & $343-674$ \\
PKC $\varepsilon$ & 3txo.1.A & $72.02 \%$ & 0.53 & 0.46 & 0.32 & -0.32 & $406-733$ \\
PKC $\zeta$ & 5li1.1.A & $84.15 \%$ & 0.57 & 0.59 & 0.39 & -0.63 & $246-585$ \\
\hline
\end{tabular}

Table 5. Homology models structure assessment.

\begin{tabular}{|c|c|c|c|c|c|}
\hline $\begin{array}{l}\text { Protein } \\
\text { Model }\end{array}$ & $\begin{array}{l}\text { MolProbity } \\
\text { Score }\end{array}$ & $\begin{array}{l}\text { Ramachandran } \\
\text { Favoured }\end{array}$ & $\begin{array}{c}\text { Ramachandran } \\
\text { Outliner }\end{array}$ & $\begin{array}{l}\text { ERRAT Overall } \\
\text { Quality Factor }\end{array}$ & $\begin{array}{l}\text { ProSA } \\
\text { Z-Score }\end{array}$ \\
\hline PKC $\gamma$ & 1.94 & $93.53 \%$ & $0.59 \%$ & 93.91 & -8.0 \\
\hline PKC & 1.08 & $96.97 \%$ & $0.00 \%$ & 89.35 & -8.59 \\
\hline $\mathrm{PKC \varepsilon}$ & 1.31 & $96.32 \%$ & $0.61 \%$ & 88.56 & -8.06 \\
\hline PKC $\zeta$ & 0.87 & $97.93 \%$ & $0.30 \%$ & 92.76 & -9.73 \\
\hline
\end{tabular}

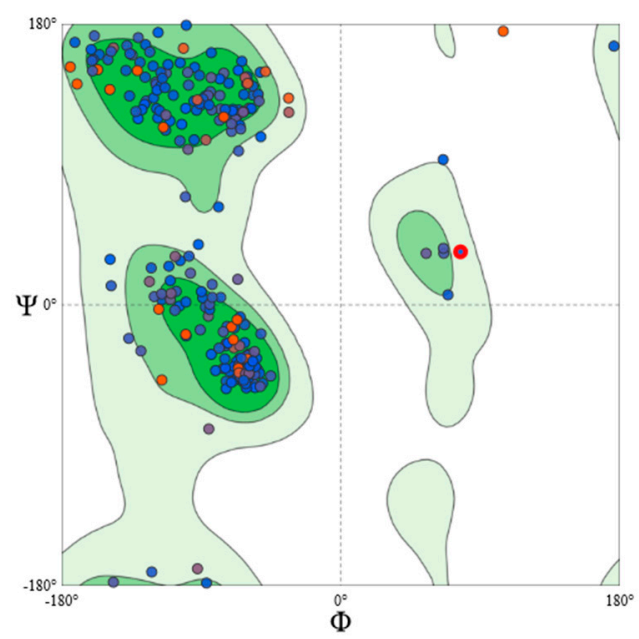

(a)

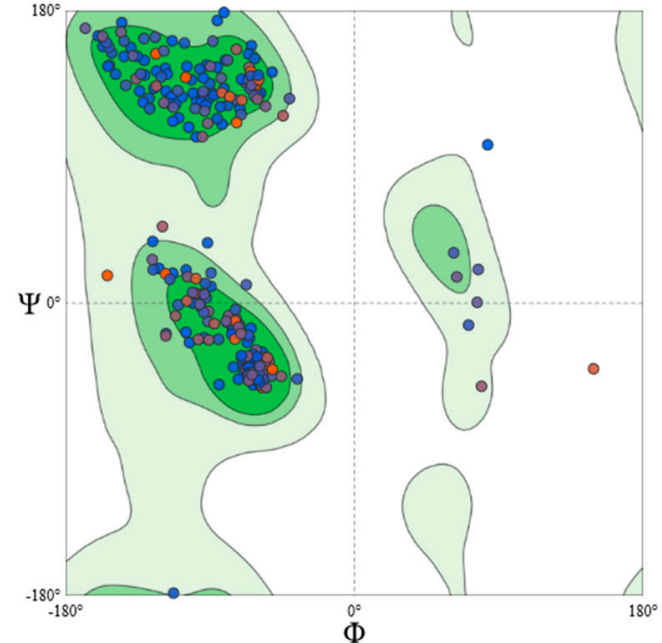

(b)

Figure 9. Ramachandran plot of (a) PKC $\gamma$ and (b) PKC $\varepsilon$. 


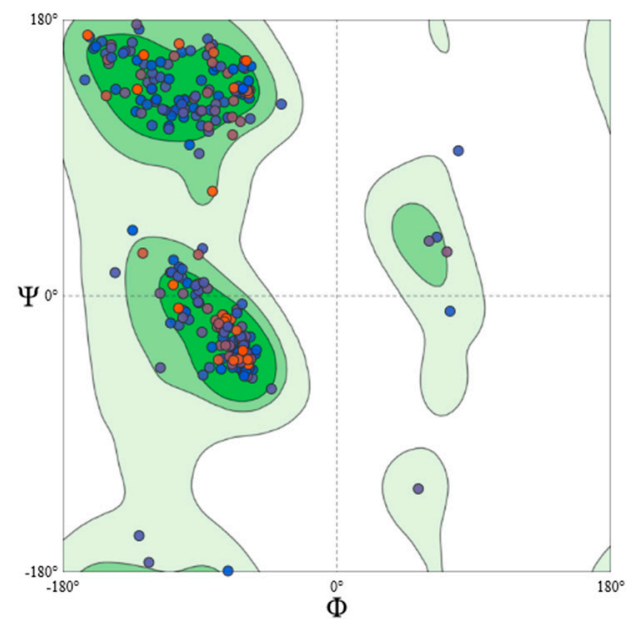

(a)

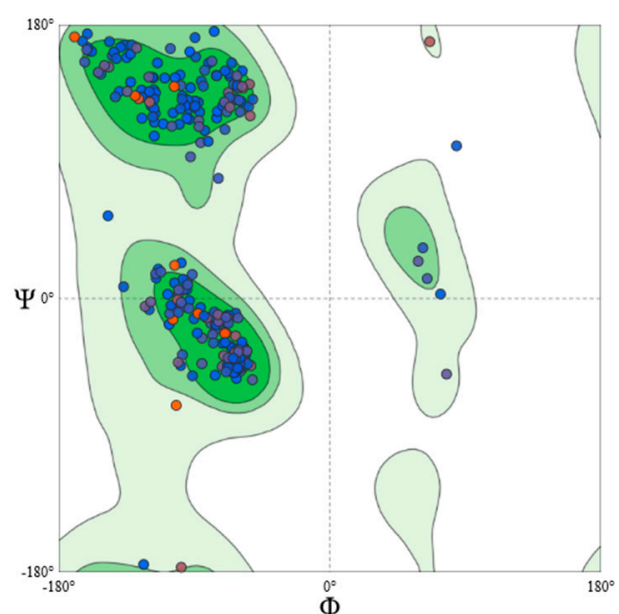

(b)

Figure 10. Ramachandran plot of (a) PKC $\delta$ and (b) PKC $\zeta$.

All the 3D X-ray crystallographic and homology modelled structures were optimized before docking using Schrödinger in-built protein preparation wizard module. Structural inconsistencies, such as missing hydrogen or incorrect bond orders, were rectified during this process. PKC $\alpha$ and PKC $\eta$ both had co-crystallized ligand, which was chosen as the centre of the receptor grid for docking. However, in the case of homology-based models, active sites were predicted using SiteMap. Active sites with binding scores $<0.9$ were rejected. The internal grid size of $x \times y \times z$ was fixed as $15 \times 15 \times 15 \AA^{3}$. Further, mmGBSA refinements were carried out on the docked poses of each isoform, with a flexible residue distance of $5.0 \AA$.

A sitemap module was used to identify the potential binding pockets. Sitemap score is based on the potential hydrogen bonding, hydrophobicity, and pocket volume. A site score greater than 0.9 is considered as a cut-off to distinguish between the potential drug binding site and non-drug binding sites [39]. The site-score and predicted residues involved in the ATP binding pocket of PKC isoforms are given in Table 6.

Table 6. The site-score and residues involved in the ATP Binding Pocket of PKC isoforms.

\begin{tabular}{|c|c|c|}
\hline PKC Isoforms & Site Score & Predicted Site Amino Acid Residue Numbers \\
\hline PKC $\gamma$ & 1.042 & $\begin{array}{c}357,358,361,362,365,378,380,399,403,418,434,435,436,437,438,439,440,444,445,448, \\
482,484,485,487,490,497,498,499,631,633,634,635,636,638,639\end{array}$ \\
\hline $\mathrm{PKC} \varepsilon$ & 1.078 & $\begin{array}{c}414,415,418,419,422,435,437,456,460,470,486,487,488,489,492,493,495,496,499,532, \\
534,536,537,539,549,550,551,552,553,697,698,699,702\end{array}$ \\
\hline PKC & 1.044 & $\begin{array}{c}258,259,260,261,262,263,264,266,279,281,314,330,331,332,333,337,339,340,343,376, \\
378,380,381,383,393,394,396,397,414,548,549,551\end{array}$ \\
\hline PKCठ & 1.037 & $\begin{array}{c}355,356,358,359,360,361,362,363,376,378,379,380,381,384,385,388,390,392,393,394, \\
396,397,399,401,411,422,427,428,429,430,434,436,437,440,471,472,473,475,477,478, \\
480,490,491,492,493,494,495,496,497,498,507,633,634,637,644,645,646\end{array}$ \\
\hline
\end{tabular}

\section{Conclusions}

Taken together, the present in vitro results reveal that DTBN inhibits the kinase activity of PKCs. Classical PKCs, PKC $\alpha$ and PKC $\gamma$, were significantly the main targets for DTBN inhibition. Molecular docking analysis of the interaction of DTBN with PKCs active sites further corroborated our results. These data point to an affinity-based effect of DTBN on PKC isozymes. The key factor to be noted here is the drug's varying behavior to mediate stabilizing interactions at the active site of individual PKCs. In silico analysis revealed a higher binding score of DTBN upon docking with PKC $\alpha$ and PKC $\gamma$. This score was reduced in the cases of PKC $\varepsilon$ and PKC $\eta$, and was further reduced in the cases of PKC $\delta$ and 
PKC $\zeta$. The selectivity of DTBN towards PKCs could guide us in targeting pathological conditions impaired in classical PKC signaling, including cancers.

Author Contributions: The manuscript was written through contributions of all authors. Conceptualization, J.G., E.L. and A.G.-G.; methodology, all authors; formal analysis, K.W., D.R.J., N.P.A., J.G., A.G.-G., E.L. and S.R.; investigation, K.W., D.R.J. and N.P.A.; resources, K.W., D.R.J., N.P.A. and E.L.; writing, K.W., D.R.J., N.P.A., J.G., A.G.-G., E.L. and S.R.; supervision, A.G.-G., J.G. and S.R. All authors have read and agreed to the published version of the manuscript.

Funding: This research was supported by The Israel Science Foundation (grant No. 1864/16 [E.L., D.R.J. and N.P.A.]. Grant (No. 3-0-7374) from the Israel Ministry of Health [A.G.G. and J.G.].

Institutional Review Board Statement: Not applicable.

Informed Consent Statement: Not applicable.

Data Availability Statement: Not applicable.

Acknowledgments: J.G. and E.L. thank Rosa Sinay for excellent technical assistance.

Conflicts of Interest: The authors declare no conflict of interest.

Sample Availability: Samples of the compounds are available from the authors.

\section{References}

1. Winer, H.; Ozer, J.; Shemer, Y.; Reichenstein, I.; Eilam-Frenkel, B.; Benharroch, D.; Golan-Goldhirsh, A.; Gopas, J. Nuphar lutea Extracts Exhibit Anti-Viral Activity against the Measles Virus. Molecules 2020, 25, 1657. [CrossRef]

2. Ozer, J.; Levi, T.; Golan-Goldhirsh, A.; Gopas, J. Anti-inflammatory effect of a Nuphar lutea partially purified leaf extract in murine models of septic shock. J. Ethnopharmacol. 2015, 161, 86-91. [CrossRef] [PubMed]

3. Padgett, D.J. A monograph of nuphar (nymphaeaceae). Rhodora 2007, 109, 1-95. [CrossRef]

4. Ozer, J.; Eisner, N.; Ostrozhenkova, E.; Bacher, A.; Eisenreich, W.; Benharroch, D.; Golan-Goldhirsh, A.; Gopas, J. Nuphar lutea thioalkaloids inhibit the nuclear factor kappaB pathway, potentiate apoptosis and are synergistic with cisplatin and etoposide. Cancer Biol. Ther. 2009, 8, 1860-1868. [CrossRef]

5. Yildirim, A.B.; Karakas, F.P.; Turker, A.U. In vitro antibacterial and antitumor activities of some medicinal plant extracts, growing in Turkey. Asian Pac. J. Trop. Med. 2013, 6, 616-624. [CrossRef]

6. Okamura, S.; Nishiyama, E.; Yamazaki, T.; Otsuka, N.; Taniguchi, S.; Ogawa, W.; Hatano, T.; Tsuchiya, T.; Kuroda, T. Action mechanism of 6,6'-dihydroxythiobinupharidine from Nuphar japonicum, which showed anti-MRSA and anti-VRE activities. Biochim. Biophys. Acta 2015, 1850, 1245-1252. [CrossRef]

7. Cullen, W.P.; LaLonde, R.T.; Wang, C.J.; Wong, C.F. Isolation and in vitro antifungal activity of 6,6'-dihydroxythiobinupharidine. J. Pharm. Sci. 1973, 62, 826-827. [CrossRef] [PubMed]

8. El-On, J.; Ozer, L.; Gopas, J.; Sneir, R.; Golan-Goldhirsh, A. Nuphar lutea: In vitro anti-leishmanial activity against Leishmania major promastigotes and amastigotes. Phytomedicine 2009, 16, 788-792. [CrossRef]

9. Ozer, L.; El-On, J.; Golan-Goldhirsh, A.; Gopas, J. Leishmania major: Anti-leishmanial activity of Nuphar lutea extract mediated by the activation of transcription factor NF-kappaB. Exp. Parasitol. 2010, 126, 510-516. [CrossRef] [PubMed]

10. Jain, S.; Jacob, M.; Walker, L.; Tekwani, B. Screening North American plant extracts in vitro against Trypanosoma brucei for discovery of new antitrypanosomal drug leads. BMC Complement Altern. Med. 2016, 16, 131. [CrossRef]

11. Matsuda, H.; Yoshida, K.; Miyagawa, K.; Nemoto, Y.; Asao, Y.; Yoshikawa, M. Nuphar alkaloids with immediately apoptosisinducing activity from Nuphar pumilum and their structural requirements for the activity. Bioorg. Med. Chem. Lett. 2006, 16, 1567-1573. [CrossRef]

12. Ozer, J.; Fishman, D.; Eilam, B.; Golan-Goldhirsh, A.; Gopas, J. Anti-Metastatic Effect of Semi-Purified Nuphar Lutea Leaf Extracts. J. Cancer 2017, 8, 1433-1440. [CrossRef] [PubMed]

13. Dalvie, E.D.; Gopas, J.; Golan-Goldhirsh, A.; Osheroff, N. 6,6'-Dihydroxythiobinupharidine as a poison of human type II topoisomerases. Bioorg. Med. Chem. Lett. 2019, 29, 1881-1885. [CrossRef]

14. Levy, D.H.; Chapple, I.L.C.; Shapira, L.; Golan-Goldhirsh, A.; Gopas, J.; Polak, D. Nupharidine enhances Aggregatibacter actinomycetemcomitans clearance by priming neutrophils and augmenting their effector functions. J. Clin. Periodontol. 2019, 46, 62-71. [CrossRef]

15. Tada, N.; Jansen, D.J.; Mower, M.P.; Blewett, M.M.; Umotoy, J.C.; Cravatt, B.F.; Wolan, D.W.; Shenvi, R.A. Synthesis and Sulfur Electrophilicity of the Nuphar Thiaspirane Pharmacophore. ACS Cent. Sci. 2016, 2, 401-408. [CrossRef]

16. Steinberg, S.F. Structural basis of protein kinase C isoform function. Physiol. Rev. 2008, 88, 1341-1378.

17. Dowling, C.M.; Kiely, P.A. Targeting Protein Kinase C Downstream of Growth Factor and Adhesion Signalling. Cancers 2015, 7, 1271-1291. [CrossRef] [PubMed] 
18. Antal, C.E.; Hudson, A.M.; Kang, E.; Zanca, C.; Wirth, C.; Stephenson, N.L.; Trotter, E.W.; Gallegos, L.L.; Miller, C.J.; Furnari, F.B.; et al. Cancer-associated protein kinase C mutations reveal kinase's role as tumor suppressor. Cell 2015, 160, 489-502. [CrossRef]

19. Xie, J.D.; Chen, S.R.; Chen, H.; Pan, H.L. Bortezomib induces neuropathic pain through protein kinase C-mediated activation of presynaptic NMDA receptors in the spinal cord. Neuropharmacology 2017, 123, 477-487. [CrossRef]

20. Muraleedharan, A.; Rotem-Dai, N.; Strominger, I.; Anto, N.P.; Isakov, N.; Monsonego, A.; Livneh, E. Protein kinase C eta is activated in reactive astrocytes of an Alzheimer's disease mouse model: Evidence for its immunoregulatory function in primary astrocytes. Glia 2021, 69, 697-714. [CrossRef]

21. Alkon, D.L.; Sun, M.K.; Nelson, T.J. PKC signaling deficits: A mechanistic hypothesis for the origins of Alzheimer's disease. Trends Pharmacol. Sci. 2007, 28, 51-60. [CrossRef] [PubMed]

22. Livneh, E.; Fishman, D.D. Linking protein kinase C to cell-cycle control. Eur. J. Biochem. 1997, 248, 1-9. [CrossRef]

23. Newton, A.C. Protein kinase C: Structure, function, and regulation. J. Biol. Chem. 1995, 270, 28495-28498. [CrossRef] [PubMed]

24. Aley, K.O.; Martin, A.; McMahon, T.; Mok, J.; Levine, J.D.; Messing, R.O. Nociceptor sensitization by extracellular signal-regulated kinases. J. Neurosci. 2001, 21, 6933-6939. [CrossRef]

25. Perluigi, M.; Barone, E.; Di Domenico, F.; Butterfield, D.A. Aberrant protein phosphorylation in Alzheimer disease brain disturbs pro-survival and cell death pathways. Biochim. Biophys. Acta 2016, 1862, 1871-1882. [CrossRef]

26. Bizzarri, M.; Dinicola, S.; Bevilacqua, A.; Cucina, A. Broad Spectrum Anticancer Activity of Myo-Inositol and Inositol Hexakisphosphate. Int. J. Endocrinol. 2016, 2016, 5616807. [CrossRef]

27. Zheng, J.; Kong, C.; Yang, X.; Cui, X.; Lin, X.; Zhang, Z. Protein kinase C-alpha (PKCalpha) modulates cell apoptosis by stimulating nuclear translocation of NF-kappa-B p65 in urothelial cell carcinoma of the bladder. BMC Cancer 2017, 17, 432. [CrossRef]

28. Leonard, B.; McCann, J.L.; Starrett, G.J.; Kosyakovsky, L.; Luengas, E.M.; Molan, A.M.; Burns, M.B.; McDougle, R.M.; Parker, P.J.; Brown, W.L.; et al. The PKC/NF-kappaB signaling pathway induces APOBEC3B expression in multiple human cancers. Cancer Res. 2015, 75, 4538-4547. [CrossRef]

29. Staal, J.; Beyaert, R. Inflammation and NF-kappaB Signaling in Prostate Cancer: Mechanisms and Clinical Implications. Cells 2018, 7, 122. [CrossRef]

30. Cooke, M.; Magimaidas, A.; Casado-Medrano, V.; Kazanietz, M.G. Protein kinase C in cancer: The top five unanswered questions. Mol. Carcinog. 2017, 56, 1531-1542. [CrossRef]

31. Mut, M.; Amos, S.; Hussaini, I.M. PKC alpha phosphorylates cytosolic NF-kappaB/p65 and PKC delta delays nuclear translocation of NF-kappaB/p65 in U1242 glioblastoma cells. Turk. Neurosurg. 2010, 20, 277-285. [CrossRef]

32. Wagner, J.; von Matt, P.; Sedrani, R.; Albert, R.; Cooke, N.; Ehrhardt, C.; Geiser, M.; Rummel, G.; Stark, W.; Strauss, A.; et al. Discovery of 3-(1H-indol-3-yl)-4-[2-(4-methylpiperazin-1-yl)quinazolin-4-yl]pyrrole-2,5-dione (AEB071), a potent and selective inhibitor of protein kinase C isotypes. J. Med. Chem. 2009, 52, 6193-6196. [CrossRef]

33. van Eis, M.J.; Evenou, J.P.; Floersheim, P.; Gaul, C.; Cowan-Jacob, S.W.; Monovich, L.; Rummel, G.; Schuler, W.; Stark, W.; Strauss, A.; et al. 2,6-Naphthyridines as potent and selective inhibitors of the novel protein kinase C isozymes. Bioorg. Med. Chem. Lett. 2011, 21, 7367-7372. [CrossRef]

34. Bi, K.; Tanaka, Y.; Coudronniere, N.; Sugie, K.; Hong, S.; van Stipdonk, M.J.; Altman, A. Antigen-induced translocation of PKC-theta to membrane rafts is required for T cell activation. Nat. Immunol. 2001, 2, 556-563. [CrossRef]

35. Waterhouse, A.; Bertoni, M.; Bienert, S.; Studer, G.; Tauriello, G.; Gumienny, R.; Heer, F.T.; de Beer, T.A.P.; Rempfer, C.; Bordoli, L.; et al. SWISS-MODEL: Homology modelling of protein structures and complexes. Nucleic Acids Res. 2018, 46, W296-W303. [CrossRef]

36. Colovos, C.; Yeates, T.O. Verification of protein structures: Patterns of nonbonded atomic interactions. Protein Sci. 1993, 2, 1511-1519. [CrossRef] [PubMed]

37. Wiederstein, M.; Sippl, M.J. ProSA-web: Interactive web service for the recognition of errors in three-dimensional structures of proteins. Nucleic Acids Res. 2007, 35, W407-W410. [CrossRef]

38. Benkert, P.; Biasini, M.; Schwede, T. Toward the estimation of the absolute quality of individual protein structure models. Bioinformatics 2011, 27, 343-350. [CrossRef]

39. Smalley, T.; Metcalf, R.; Patel, R.; Islam, S.M.A.; Bommareddy, R.R.; Acevedo-Duncan, M. The Atypical Protein Kinase C Small Molecule Inhibitor zeta-Stat, and Its Effects on Invasion through Decreases in PKC-zeta Protein Expression. Front. Oncol. 2020, 10, 209. [CrossRef] 